\title{
Production and Performance Evaluation of External Quality Assessment Materials for Human Epididymis Protein 4 Assay
}

Anna Lee and

Hee-Jung Kim

Department of Laboratory

Medicine, Seoul Clinical

Laboratories, Yongin, Korea

Corresponding author:

\section{Anna Lee}

Department of Laboratory

Medicine, Seoul Clinical

Laboratories, 23F, Heungdeok

IT valley, 13 Heungdeok 1-ro,

Giheung-gu, Yongin 16954,

Korea

Tel: +82-2-330-2012

Fax: +82-2-790-6509

E-mail: anlee@scllab.co.kr

pISSN: 2384-2458

eISSN: 2288-7261
Background: External quality assessment (EQA) is important for standardizing cancer biomarker assays, thereby, ensuring accurate and precise results. Although the human epididymis-specific protein 4 (HE4) assay has been increasingly used to detect and monitor ovarian malignancy in Korea, a nation-wide EQA program for HE4 has not been appropriately established. To conduct an EQA program, a large amount of quality control (QC) materials are required. This study aimed to produce HE4 QC materials for an EQA program and evaluate their homogeneity and stability.

Methods: QC materials for three different concentrations of HE4 were produced from the collected remnant sera of 275 patients for whom the HE4 assays were performed. These materials were evaluated for homogeneity between vials and stability during storage. The frozen QC materials were distributed to 13 representative organizations for a provisional EQA.

Results: The total coefficient of variation of the HE4 QC materials of three concentrations was $0.75 \%-1.24 \%$, and no significant differences were noted between vials; therefore, the samples were considered to be homogenous. With respect to stability, the HE4 QC materials were found to be stable till 30 days when frozen and for 24 hours when refrigerated. The results of the provisional HE4 EQA were reviewed and the survey results were reported to each participant.

Conclusions: The HE4 QC materials produced from remnant specimens were found to be homogenous between vials and stable in a frozen condition until 30 days. The findings of this study may be practically applied for establishing a future HE4 EQA program.

(J Lab Med Qual Assur 2019;41:153-160)

Key Words: Human epididymis-specific protein 4, Ovarian neoplasms, External quality assessment, Quality control

Received June 8, 2019, Revision received July 5, 2019, Accepted July 8, 2019

\section{서론}

2016년 국가암등록통계에 의하면 국내 난소암의 유병 현황 은 여성에서 발생하는 전체 암종의 $2.0 \%$ 를 차지하며, 조유병 률은 인구 100,000 명당 76.3 명으로 여성에서 발생하는 암종 중 8번째로 높다[1]. 난소암은 초기에는 무증상인 경우가 대부 분이고, 증상이 있더라도 비특이적므로 양성질환과 감별이 어 려워 $70 \%$ 이상의 난소암이 진행된 상태에서 발견된다. 난소 암은 I-II기에 조기 발견 시 5년 생존율이 80\%-90\%로 높으나, 병기가 진행되어 III-IV기에 발견되는 경우 생존율이 $30 \%$ 로
낮으므로[2], 난소암의 조기진단은 생존율 향상에 매우 중요 하다.

난소암을 진단하기 위한 검사법으로는 골반초음파와 혈 청 cancer antigen 125 (CA-125) 검사가 주로 이용되어 왔 다. 인간부고환단백4 (human epididymis protein 4, HE4) 는 CA- 125 와 보완적으로 난소암의 조기 진단 및 재발 여부 확인을 위한 검사로 개발되어 2011년 미국 Food and Drug Administration (FDA)로부터 허가를 받았다[3]. 국내에서 도 그 안전성과 유효성에 대해 2014년 2월 21일 신의료기술평 가 고시(보건복지부 고시 제2014-32호)가 공표되었으며, 이 
후 국내에서 HE4 검사의 사용이 급증하고 있다. 또한 2016년 11월 1일 HE4 검사에 대한 요양급여 적용이 고시되었고(나 $437 \mathrm{C} 4370)$, 보험심사평가원 보건의료빅데이터시스템에 의 하면 2017년 한해 청구된 HE4 연간 총 사용량은 67,084 건으 로 $\mathrm{HE} 4$ 검사의 국내 사용량이 지속적으로 증가하고 있다(Fig. 1). 검체 검사 전문기관인 본 검사실에 의뢰되는 $\mathrm{HE} 4$ 검사량 또한 최근 수년 사이에 급증하고 있으며(Fig. 2), 2018년 기 준, HE4 검사의 연간 검사 건수는 기존 난소암 종양표지자로 가장 많이 사용되는 CA-125 연간 검사 건수의 약 $28.3 \%$ 를 차 지하였다. 따라서 HE4 검사는 난소암 진단 및 치료 후 추적을 위한 검사로서 향후 그 임상적 요구도가 더욱 증가할 것으로 생각된다.

미국의 College of American Pathologists (CAP) 주관 정 도관리프로그램에는 HE4 검사에 대한 survey가 2017년부터
신설되어 운용되고 있다. 하지만 국내에는 HE4 검사에 대한 신빙도조사프로그램이 아직 마련되어 있지 않아 HE4 검사의 외부정도관리에 어려움이 있다. 이에 본 연구에서는 최근 새로 운 난소암 종양표지자로서 국내에서 임상적 사용이 급증하고 있는 $\mathrm{HE} 4$ 검사에 대한 외부정도관리물질을 제조하여 그 적합 성을 평가하고 $\mathrm{HE} 4$ 모의신빙도조사를 실시하고자 하였다.

\section{재료 및 방법}

\section{1. 대상}

2017년 4월 27일부터 7월 31일까지 (재)서울의과학연구소 에 $\mathrm{HE} 4$ 검사가 의뢰된 환자를 대상으로 $\mathrm{HE} 4$ 검사 완료 후 잔 여혈청을 이용, B형 간염 표면항원, C형 간염 항체 및 human immunodeficiency virus (HIV) 항체검사를 실시하였다. 세

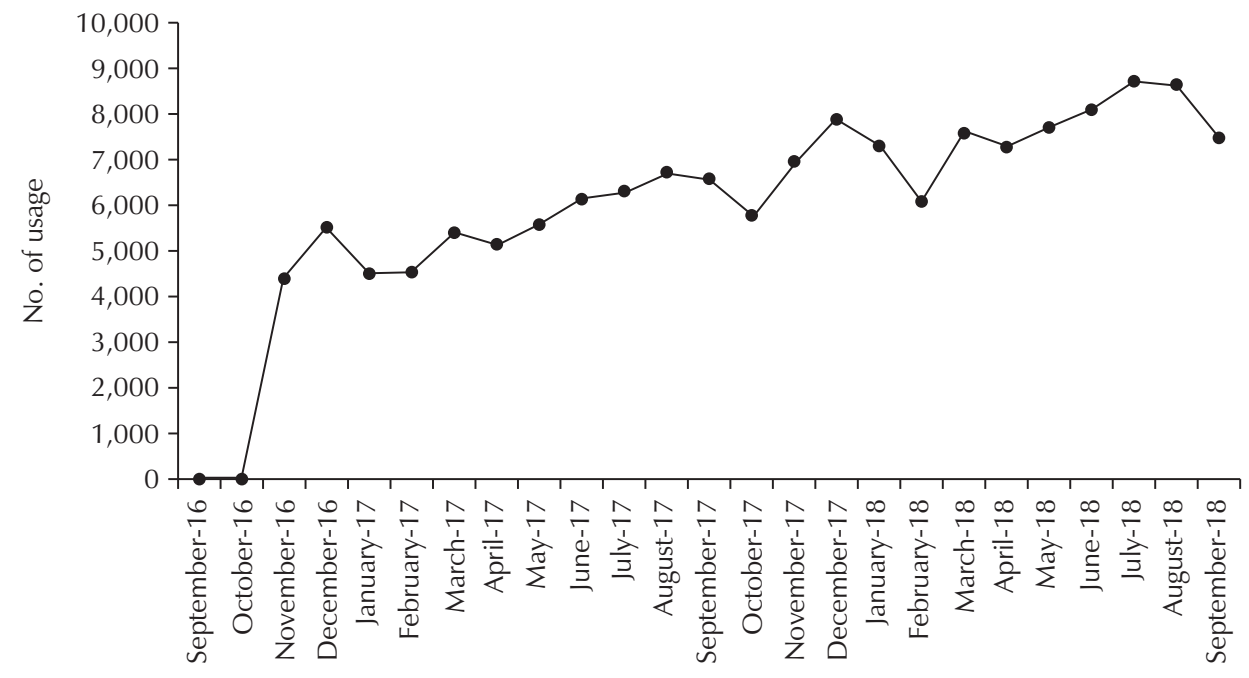

Fig. 1. Monthly trend of human epididymis protein 4 test usage reimbursed, based on the data from Bigdata Hub provided by the Health Insurance Review and Assessment Service.

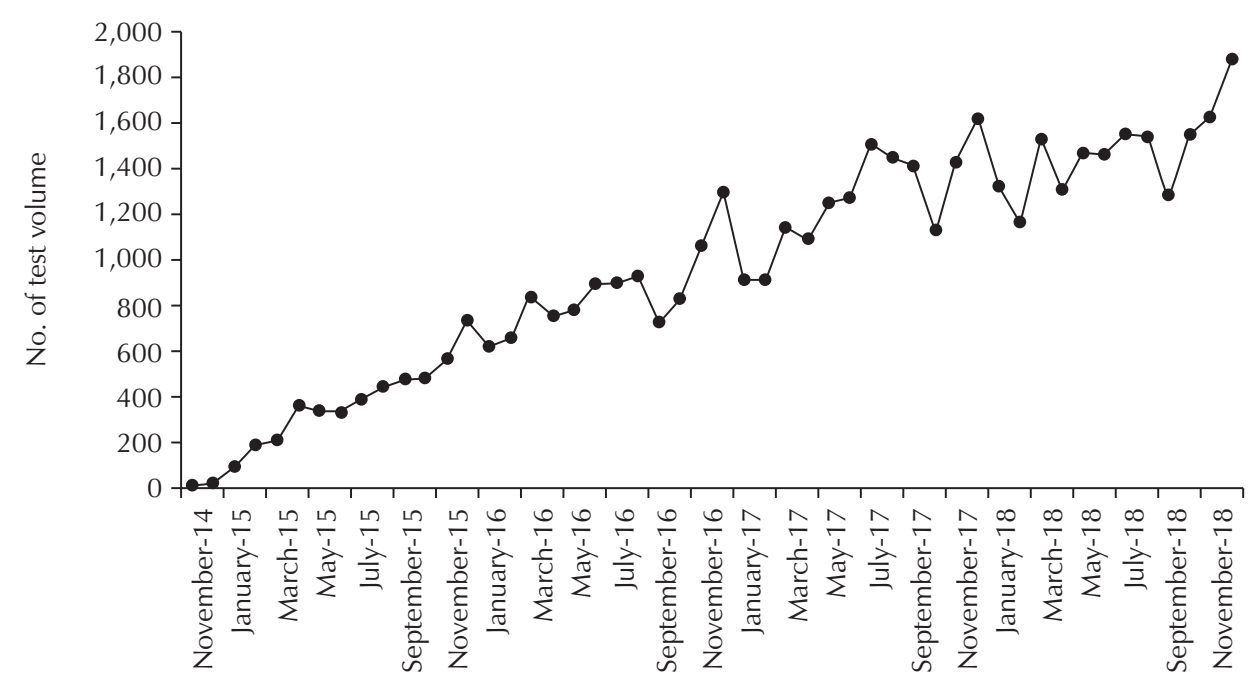

Fig. 2. Monthly test volume for human epididymis protein 4 assay in a referral laboratory. 
검사 모두 음성인 잔여 혈청 275 개를 수집하였고 $\mathrm{HE} 4$ 정도관 리물질 제조 시까지 냉동 $\left(-20^{\circ} \mathrm{C}\right)$ 하였다. 본 연구는 (재)서울 의과학연구소 기관생명심의위원회로부터 심의(2017-43-01F) 를 득한 후 진행되었다.

\section{Human epididymis protein 4 정도관리물질의 제조}

개별 혈청의 $\mathrm{HE} 4$ 농도에 따라 혈청을 세 군으로 대분하여 $-20^{\circ} \mathrm{C}$ 에 냉동 보관하였고, 냉동혈청을 실온에서 완전히 해 동한 후 혼합하여 세 가지 다른 농도의 혼주혈청을 제조하였 다. 혼주혈청에는 $10 \%$ sodium azide (Sigma-Aldrich, St. Louis, MO, USA) 용액을 $1 \%$ 농도로 첨가한 후 교반기에서 $180 \mathrm{rpm}$ 의 속도로 10 분간 혼합하였다. 혼주혈청을 멸균거즈 에 걸러 섬유소를 제거하였고, 세 농도의 혼주혈청을 각 1.0 $\mathrm{mL}$ 씩 멸균된 $2.0 \mathrm{~mL}$ Cryogenic vial (Corning Life Science, New York, NY, USA)에 분주하여 뚜껑을 닫고 파라핀 필름 으로 봉한 후 다시 냉동하여 $\left(-20^{\circ} \mathrm{C}\right)$ 보관하였다.

\section{3. 검사방법}

$\mathrm{HE} 4$ 와 B형 간염 표면항원검사는 Cobas e602 (Roche Diagnostics GmbH, Mannheim, Germany)를 이용하 여 전자화학발광 면역분석법(electro-chemiluminescent immunoassay)으로 검사하였다. C형 간염 항체와 $\mathrm{HIV}$ 항체 검사는 ARCHITECT i2000 (Abbott Laboratories, Abbott Park, IL, USA)을 이용하여 화학발광 미세입자 면역분석법 (chemiluminescent microparticle immunoassay)으로 검사 하였다.

냉동된 $\mathrm{HE} 4$ 혼주혈청은 실온 $\left(20^{\circ} \mathrm{C}-25^{\circ} \mathrm{C}\right)$ 에서 해동 후 교 반기를 이용, 충분히 혼합한 후 HE4 농도를 측정하였다. 시 약 제조사가 제시한 $\mathrm{HE} 4$ 검사의 정밀도는 $2.6 \%-3.4 \%$ (평균 농도, 27.4-1390.0 pmol/L 범위; Cobas e602 장비 기준)이다. 연구에 사용된 HE4 검사는 모두 한 시약 lot로 검사하였고, 해 당 lot를 사용하기 전 장비의 보정을 시행한 후 검사하였다. 매 검사 전 PreciControl HE4 (Roche Diagnostics $\mathrm{GmbH}$ )를 이 용하여 두 농도의 내부정도관리 결과가 허용범위 이내임을 확 인한 후 실험을 진행하였다.

\section{Human epididymis protein 4 정도관리물질의 용기 간 균질 성 평가}

분주한 $\mathrm{HE} 4$ 외부정도관리물질이 용기 간 균질한지 확인하 기 위하여 세 농도별 각 10 개의 용기를 임의로 선정한 후 용기 당 3회씩 HE4 농도를 반복 측정하였다.

\section{Human epididymis protein 4 정도관리물질의 안정성 평가}

$\mathrm{HE} 4$ 정도관리물질의 보관조건에 따른 안정성을 평가하기 위하여 세 농도의 정도관리물질을 냉동 $\left(-20^{\circ} \mathrm{C}\right)$, 냉장 $\left(4^{\circ} \mathrm{C}\right)$ 및 실온 $\left(20^{\circ} \mathrm{C}\right.$ )에서 각각 24 시간, 3 일, 7 일, 14 일, 30 일 및 90 일 동 안 보관하였다. 각 보관온도 및 기간별로 용기당 3 회씩 $\mathrm{HE} 4$ 농도를 반복 측정하였다.

\section{6. 제조된 human epididymis protein 4 정도관리물질을 이용 한 모의신빙도조사}

국내에서 HE4 검사를 시행 중인 기관에 이메일을 발송하여 $\mathrm{HE} 4$ 모의신빙도조사에 대한 참여 의향을 파악하였다. 13 개 기관에서 모의신빙도조사를 요청하였고, 해당 기관에 각 세 농 도의 $\mathrm{HE} 4$ 정도관리물질을 발송하였다. 외부정도관리물질은 냉동상태를 유지하여 배송되도록 보냉재질로 이중포장 후 드 라이아이스를 $6 \mathrm{~kg}$ 씩 스티로폼 상자에 추가하여 통상 택배로 발송하였다. 정도관리 결과의 회신 서식에는 HE4 정도관리물 질 수령 시 냉동상태 유지 여부를 기입하도록 하여 냉동검체 수송방법에 대한 적정성을 평가하였다.

\section{7. 통계분석}

모든 통계분석에는 Analyse-it Software ver. 4.92.4 (Analyse-it Software Ltd., Leeds, UK)를 사용하였다. HE4 정도관리물질의 용기 간 균질도 평가 시 각 농도별 10 개의 용 기에 대한 3회 반복측정치의 총 변이계수(total coefficient of variation $[\mathrm{CV}])$ 를 계산하였고, 용기 간 통계적으로 유의한 차이가 있는지 analysis of variance로 평가하였다. 보관조건 에 따른 안정성 평가에 있어 각 농도별 $\mathrm{HE} 4$ 기저치(냉동보 관 후 24 시간 경과한 검체를 해동 후 3 회 반복 측정한 $\mathrm{HE} 4$ 결 과치)와 각 보관온도별, 기간별 3회 반복측정치를 'Dunnett against a control comparisons'로 분석하였다. $P$ 값이 0.05 미만인 경우 통계적으로 유의한 것으로 판정하였다. 또한 13 개 기관에서 회신한 HE4 모의신빙도조사 결과에 대하여 시 약별로 참가기관의 평균, 표준편차 및 각 기관의 standard deviation index를 계산하여 보고서 형태로 회신하였다.

\section{결과}

\section{1. 연구기간 동안의 human epididymis protein 4 내부정도관 리 결과}

$\mathrm{HE} 4$ 외부정도관리물질의 균질성 및 안정성 시험을 진행한 90일 동안 HE4 내부정도관리 결과는 total CV 2.53\% (mean土 standard deviation [SD], $48.27 \pm 1.22 \mathrm{pmol} / \mathrm{L}$ ) 및 2.51\% 


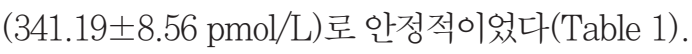

\section{Human epididymis protein 4 외부정도관리물질의 균질성 평가 결과}

$\mathrm{HE} 4$ 외부정도관리물질의 용기 간 균질성 평가에서 level 별 각 10 개 용기에 대한 3 회 반복검사의 total CV는 다음과 같 았다: level I, 1.24\% (mean HE4, $39.50 \mathrm{pmol} / \mathrm{L}$ ); level II, 1.08\% (mean HE4, $91.81 \mathrm{pmol} / \mathrm{L}$ ); level III, 0.75\% (mean $\mathrm{HE} 4,330.26 \mathrm{pmol} / \mathrm{L}$ ). 세 level의 정도관리물질 모두 용기 간 $\mathrm{HE} 4$ 농도에 유의한 차이가 없어 균질한 것으로 평가하였다 (Table 2).

\section{Human epididymis protein 4 정도관리물질의 안정성 평가 결과}

보관조건에 따른 안정성 평가에서 HE4 정도관리물질의 냉 동보관 시 세 농도 모두 30 일까지는 기저치(냉동 후 24시간)
와 유의한 차이가 없었으나, 90 일 후에는 기저치와 유의한 차 이를 보였다. 냉장보관 시 24시간까지는 세 농도 모두 기저치 와 차이가 없었으나, 냉장 후 3일 후부터는 HE4 농도가 유의 하게 감소되어 시간이 지날수록 그 감소폭이 커졌다. 실온보관 시에는 24 시간에도 기저치와 유의한 차이가 있었고, 점차 감 소 폭이 커져 30일에 가장 낮은 농도를 보이다가 90 일 후에는 농도가 약간 증가하였다(Table 3, Fig. 3).

\section{Human epididymis protein 4 정도관리물질에 대한 모의신 빙도조사 결과}

국내 13 개 기관에 발송한 세 농도의 HE4 정도관리물질은 한 기관만을 제외하고는 모두 냉동상태가 유지된 채 각 기관에 배송되었음을 확인하였다. 정도관리물질이 해동되었다고 답 변한 한 기관의 경우는 정도관리물질이 원내 택배 수령처에서 14 시간 이상 방치되었던 예로, 이후 정도관리물질을 재발송하 였다. HE4 시약(Abbott 및 Roche) 사용기관별로 HE4 예비

Table 1. Results of the internal QC testing for HE4 to assess the homogeneity and stability during the 90-day evaluation period

\begin{tabular}{|c|c|c|c|c|c|}
\hline \multirow{2}{*}{ QC materials } & \multirow{2}{*}{$\begin{array}{l}\text { QC target mean (range) } \\
(\mathrm{pmol} / \mathrm{L})\end{array}$} & \multicolumn{2}{|c|}{$\begin{array}{l}6 \text { Testing days during } \\
\text { 90-day evaluation }\end{array}$} & \multicolumn{2}{|c|}{ During 90-day evaluation } \\
\hline & & $\begin{array}{c}\operatorname{Mean} \pm \mathrm{SD} \\
(\mathrm{pmol} / \mathrm{L})\end{array}$ & CV (\%) & $\begin{array}{c}\text { Mean } \pm \text { SD } \\
(\mathrm{pmol} / \mathrm{L})\end{array}$ & $\mathrm{CV}(\%)$ \\
\hline PreciControl HE4 1 & $48.41(45.32-51.5)$ & $47.89 \pm 1.30$ & 2.70 & $48.27 \pm 1.22$ & 2.53 \\
\hline PreciControl HE4 2 & $350.77(328.9-372.6)$ & $348.32 \pm 6.42$ & 1.84 & $341.19 \pm 8.56$ & 2.51 \\
\hline
\end{tabular}

Abbreviations: QC, quality control; HE4, human epididymis protein 4; SD, standard deviation; CV, coefficient of variation.

Table 2. Variation in the concentrations of HE4 detected among vials in the three levels of EQA materials

\begin{tabular}{|c|c|c|c|c|c|c|c|}
\hline \multirow{2}{*}{ Vial no. } & \multirow{2}{*}{ No. } & \multicolumn{2}{|c|}{ Level I (pmol/L) } & \multicolumn{2}{|c|}{ Level II (pmol/L) } & \multicolumn{2}{|c|}{ Level III (pmol/L) } \\
\hline & & Mean \pm SD & CV (\%) & Mean \pm SD & CV (\%) & Mean \pm SD & $\mathrm{CV}(\%)$ \\
\hline Vial 1 & 3 & $39.68 \pm 0.41$ & 1.03 & $92.11 \pm 0.75$ & 0.81 & $327.17 \pm 1.76$ & 0.54 \\
\hline Vial 2 & 3 & $39.51 \pm 0.38$ & 0.97 & $91.51 \pm 0.87$ & 0.95 & $330.00 \pm 1.35$ & 0.41 \\
\hline Vial 3 & 3 & $39.58 \pm 0.18$ & 0.46 & $91.10 \pm 0.19$ & 0.21 & $331.67 \pm 2.51$ & 0.76 \\
\hline Vial 4 & 3 & $39.43 \pm 0.25$ & 0.63 & $91.62 \pm 1.45$ & 1.59 & $331.33 \pm 1.68$ & 0.51 \\
\hline Vial 5 & 3 & $39.35 \pm 0.09$ & 0.22 & $91.57 \pm 0.75$ & 0.82 & $331.40 \pm 4.34$ & 1.31 \\
\hline Vial 6 & 3 & $39.24 \pm 0.33$ & 0.83 & $92.15 \pm 1.07$ & 1.17 & $331.70 \pm 1.04$ & 0.31 \\
\hline Vial 7 & 3 & $39.33 \pm 0.40$ & 1.01 & $91.03 \pm 0.37$ & 0.40 & $328.73 \pm 2.94$ & 0.89 \\
\hline Vial 8 & 3 & $39.97 \pm 1.28$ & 3.21 & $91.86 \pm 1.24$ & 1.35 & $330.13 \pm 0.91$ & 0.27 \\
\hline Vial 9 & 3 & $39.41 \pm 0.25$ & 0.64 & $91.98 \pm 0.64$ & 0.70 & $330.20 \pm 2.81$ & 0.85 \\
\hline Vial 10 & 3 & $39.52 \pm 0.18$ & 0.45 & $93.20 \pm 0.64$ & 1.40 & $330.30 \pm 3.20$ & 0.97 \\
\hline Total & 30 & $39.50 \pm 0.45$ & 1.24 & $91.81 \pm 0.99$ & 1.08 & $330.26 \pm 2.48$ & 0.75 \\
\hline$P$-value* & 30 & \multicolumn{2}{|c|}{0.8284} & \multicolumn{2}{|c|}{0.7723} & \multicolumn{2}{|c|}{0.4695} \\
\hline
\end{tabular}

Abbreviations: HE4, human epididymis protein 4; EQA, external quality control; SD, standard deviation; CV, coefficient of variation. *Significant results with $P$-values less than 0.05 (by analysis of variance). 
Journal of LABORATORY MEDICINE and QUALITY ASSURANCE

Anna Lee et al • External Quality Assessment of HE4

Table 3. HE4 concentration after storage under three different conditions $\left(4^{\circ} \mathrm{C}, 20^{\circ} \mathrm{C}\right.$, and $\left.-4^{\circ} \mathrm{C}\right)$ on days $1,3,14,30$, and 90

\begin{tabular}{|c|c|c|c|c|c|c|c|c|}
\hline \multirow{2}{*}{ Level } & \multirow{2}{*}{$\begin{array}{l}\text { Storage } \\
\text { condition }\end{array}$} & \multirow{2}{*}{ Category } & \multicolumn{6}{|c|}{ HE4 stability test } \\
\hline & & & Day $1(n=3)$ & Day $3(n=3)$ & Day $7(n=3)$ & Day $14(n=3)$ & Day $30(n=3)$ & Day $90(n=3)$ \\
\hline \multirow[t]{9}{*}{ I } & $-20^{\circ} \mathrm{C}$ & Mean $(\mathrm{pmol} / \mathrm{L})$ & 39.91 & 39.89 & 39.36 & 40.61 & 40.99 & 38.59 \\
\hline & & $P$-value & - & 1.000 & 0.5799 & 0.3854 & 0.0955 & 0.0347 \\
\hline & & CV (\%) & 0.87 & 0.58 & 0.14 & 0.42 & 1.02 & 2.89 \\
\hline & $4^{\circ} \mathrm{C}$ & Mean $(\mathrm{pmol} / \mathrm{L})$ & 39.99 & 38.89 & 35.76 & 33.64 & 27.46 & 16.68 \\
\hline & & $P$-value & 0.993 & 0.0079 & $<0.0001$ & $<0.0001$ & $<0.0001$ & $<0.0001$ \\
\hline & & CV (\%) & 1.19 & 1.00 & 0.96 & 0.60 & 0.55 & 1.37 \\
\hline & $20^{\circ} \mathrm{C}$ & Mean (pmol/L) & 37.84 & 32.77 & 24.83 & 19.30 & 15.84 & 18.64 \\
\hline & & $P$-value & 0.0285 & $<0.0001$ & $<0.0001$ & $<0.0001$ & $<0.0001$ & $<0.0001$ \\
\hline & & CV (\%) & 0.63 & 0.31 & 0.24 & 0.42 & 7.16 & 9.10 \\
\hline \multirow[t]{9}{*}{ II } & $-20^{\circ} \mathrm{C}$ & Mean $(\mathrm{pmol} / \mathrm{L})$ & 76.22 & 75.90 & 74.78 & 76.86 & 76.90 & 74.35 \\
\hline & & $P$-value & - & 0.9663 & 0.0874 & 0.6928 & 0.6424 & 0.0230 \\
\hline & & $\mathrm{CV}(\%)$ & 1.15 & 0.45 & 0.48 & 0.29 & 1.59 & 0.71 \\
\hline & $4^{\circ} \mathrm{C}$ & Mean (pmol/L) & 75.66 & 73.80 & 68.02 & 63.95 & 52.92 & 32.05 \\
\hline & & $P$-value & 0.8454 & 0.0051 & $<0.0001$ & $<0.0001$ & $<0.0001$ & $<0.0001$ \\
\hline & & CV (\%) & 1.82 & 0.57 & 0.60 & 1.10 & 0.53 & 0.77 \\
\hline & $20^{\circ} \mathrm{C}$ & Mean $(\mathrm{pmol} / \mathrm{L})$ & 74.22 & 62.13 & 46.38 & 36.62 & 28.95 & 33.32 \\
\hline & & $P$-value & 0.2400 & $<0.0001$ & $<0.0001$ & $<0.0001$ & $<0.0001$ & $<0.0001$ \\
\hline & & CV (\%) & 3.74 & 1.24 & 0.44 & 0.88 & 1.17 & 5.35 \\
\hline \multirow[t]{9}{*}{ III } & $-20^{\circ} \mathrm{C}$ & Mean (pmol/L) & 338.63 & 339.27 & 338.83 & 344.93 & 350.13 & 335.17 \\
\hline & & $P$-value & 1.000 & 0.999 & 1.000 & 0.2410 & 0.0121 & 0.7539 \\
\hline & & CV (\%) & 1.53 & 0.26 & 0.59 & 0.33 & 0.71 & 1.82 \\
\hline & $4{ }^{\circ} \mathrm{C}$ & Mean (pmol/L) & 337.17 & 330.80 & 307.13 & 296.10 & 250.37 & 176.23 \\
\hline & & $P$-value & 0.9356 & 0.0063 & $<0.0001$ & $<0.0001$ & $<0.0001$ & $<0.0001$ \\
\hline & & $\mathrm{CV}(\%)$ & 0.79 & 0.21 & 0.35 & 0.44 & 0.56 & 0.57 \\
\hline & $20^{\circ} \mathrm{C}$ & Mean (pmol/L) & 328.13 & 288.33 & 228.70 & 188.43 & 159.70 & 172.87 \\
\hline & & $P$-value & 0.0333 & $<0.0001$ & $<0.0001$ & $<0.0001$ & $<0.0001$ & $<0.0001$ \\
\hline & & CV (\%) & 1.29 & 0.28 & 1.29 & 2.12 & 2.67 & 3.17 \\
\hline
\end{tabular}

Significant results with $P$-values less than 0.05 when compared with baseline values ( 1 day after freezing) are expressed in red color (derived using Dunnett's test).

Abbreviations: HE4, human epididymis protein 4; CV, coefficient of variation.

신빙도조사 결과를 나누어 분석하였고(Table 4), 보고서 양식 에 분석결과를 작성하여 각 기관에 회신하였다.

\section{고찰}

국내 난소암 환자의 5 년 생존율은 $64.1 \%$ 로, 유방암 $(92.3 \%)$ 과 자궁경부암(79.9\%)에 비해 생존율이 더 낮다. 세부적으 로 보면 난소 안에 국한되어 있거나(localized), 난소 근처 장 기에 국한된(regional) 난소암은 5년 생존율이 각각 $92.7 \%$ 및
$76.7 \%$ 로 높지만, 원격 전이된(distant) 경우 $42.3 \%$ 로 생존율 에 차이가 크므로 난소암 조기진단의 중요성이 매우 크다고 할 수 있다[4]. Koshiyama 등[5]은 아시아 여성에서 공격적인 유형(type II)보다는 예후가 양호한 유형(type I)의 난소암 빈 도가 보다 높으며, 따라서 아시아 여성에 있어 특히 CA-125/ 질경유초음파촬영술(transvaginal sonography)과 같은 난소 암 선별검사의 중요성을 강조한 바 있다.

혈청 CA-125 검사는 상피성 난소암의 가장 중요한 종양표 지자 중 하나로, 여러 학술단체의 지침에서 난소암의 감별진 
A

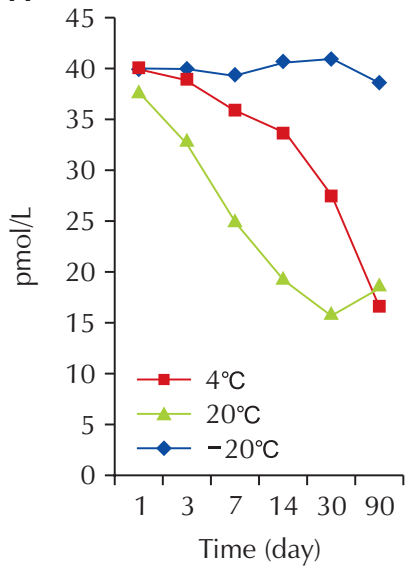

B

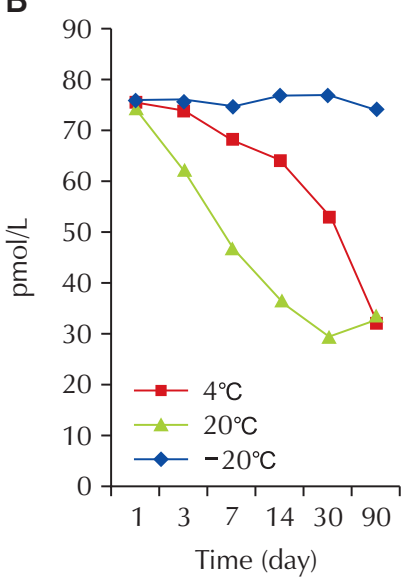

C

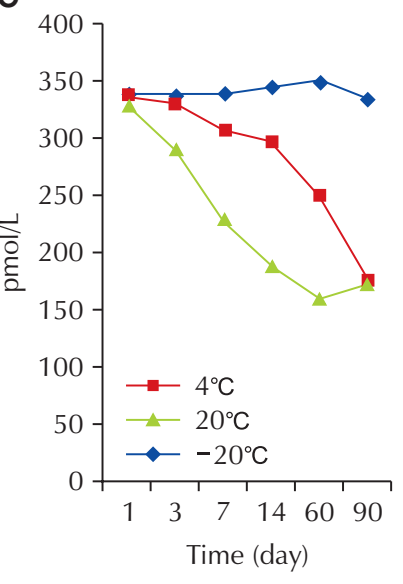

Fig. 3. Human epididymis protein 4 concentration after storage under three different conditions $\left(4^{\circ} \mathrm{C}, 20^{\circ} \mathrm{C}\right.$, and $\left.-4^{\circ} \mathrm{C}\right)$ at days $1,3,14,30$, and 90 . Level I (A), level II (B), and level III (C).
Table 4. Results of the provisional external quality control for the human epididymis protein 4 assay from 13 laboratories

\begin{tabular}{llccc}
\hline Level & Manufacturer & $\begin{array}{c}\text { No. of } \\
\text { labora- } \\
\text { tories }\end{array}$ & $\begin{array}{c}\text { Mean } \pm \text { SD } \\
\text { (pmol/L) }\end{array}$ & CV (\%) \\
\hline I & Abbott & 5 & $41.20 \pm 4.67$ & 11.3 \\
& Roche & 8 & $40.21 \pm 0.89$ & 2.2 \\
II & All methods & 13 & $40.59 \pm 2.83$ & 7.0 \\
& Abbott & 5 & $95.92 \pm 8.33$ & 8.7 \\
& Roche & 8 & $92.84 \pm 2.33$ & 2.5 \\
III & All methods & 13 & $94.03 \pm 5.36$ & 5.7 \\
& Abbott & 5 & $373.08 \pm 42.82$ & 11.5 \\
& Roche & 8 & $328.00 \pm 10.69$ & 3.3 \\
& All methods & 13 & $345.34 \pm 34.63$ & 10.0 \\
\hline
\end{tabular}

The instruments were from the following companies: Abbott Laboratories (Abbott Park, IL, USA) and Roche Diagnostics GmbH (Mannheim, Germany).

Abbreviations: SD, standard deviation; CV, coefficient of variation.

단, 예후 추정, 치료경과 관찰과 치료 후 추적에 CA-125 사용 을 권고하고 있다[6]. 하지만 CA-125는 폐경 전 여성에서 생 리 시 증가할 수 있고, 임신이나 양성 부인과 질환에서도 증가 될 수 있으며, 난소암이 아닌 다른 장기의 종양에서도 상승을 보여 그 특이도가 낮다는 단점이 있다 $[7,8]$. 뿐만 아니라 조기 상피성 난소암에서는 CA-125 농도가 경미한 정도로 증가되거 나 또는 증가되지 않을 수도 있어 조기암에 대해서는 민감도가 $50 \%-62 \%$ 밖에 되지 않는다는 단점도 있다[6].

CA-125의 이러한 단점을 보완하기 위하여 다른 난소암 표 지자에 대한 많은 연구가 진행되어 왔고, $\mathrm{HE} 4$ 가 골반 종괴의 감별진단, 난소암의 진단, 치료효과, 예후 판정과 재발 예측에 도움이 되는 것으로 보고되면서 새로운 난소암 표지자로서 주
목받게 되었다[3]. HE4는 상피성 난소암에서 과발현되며, 조 직학적 유형 중 발생빈도가 가장 높은 장액성 난소암(serous carcinoma)의 $93 \%$, 자궁내막양 난소암(endometrioid carcinoma)의 $100 \%$ 에서 분비된다[9]. HE4는 특히 폐경 전 여성에서 양성과 악성의 골반 종괴를 감별함에 있어 CA-125 보다 진단적 특이도가 높으며[8], CA-125와 HE4를 동시 측 정 시 상피성 난소암 위험군 선별검사로서의 민감도가 더 높아 지는 것으로 보고되어 있다[10]. 또한 2009년 Moore 등[11]이 제안한 Risk of Ovarian Malignancy Algorithm (ROMA)는 $\mathrm{HE} 4$ 및 CA-125 결과와 폐경 상태를 합하여 골반 종괴를 가 진 여성의 난소암 위험도(risk)를 계산하도록 만든 알고리즘 으로, 2011년 미국 FDA로부터 허가를 받았고, 국내에서도 최 근 많이 이용되고 있다.

최근 임상적 사용이 급증하고 있는 $\mathrm{HE} 4$ 검사에 대한 임상 적 진단효율성을 높이기 위해서는 면밀한 질 관리를 통하여 $\mathrm{HE} 4$ 농도를 정밀하고 정확하게 측정함이 필수적이다. 현재 CA-125에 대한 국내 외부정도관리는 대한임상정도관리협회 주관 신빙도조사프로그램에서 주관하는 종양표지자검사 II에 포함되어 있으나. HE4 검사에 대해서는 아직 국내 외부정도 관리프로그램이 마련되어 있지 않다. 향후 HE4 검사에 대한 외부정도관리프로그램을 도입한다면, CA- $125, \mathrm{HE} 4$ 와 함께 ROMA index를 같이 포함시켜 외부정도관리프로그램을 운용 하는 것이 보다 바람직할 것으로 생각된다.

외부정도관리를 시행하기 위해서는 많은 양의 정도관리물질 이 필요한데, 이러한 정도관리물질의 기질효과를 최소화하기 위하여 일반인 및 진단된 암 환자로부터 대량의 혈액을 채취하 고 분주하여 정도관리물질을 제조하는 방법을 고려할 수 있겠 다. 하지만 이 경우 안전성이나 윤리적 문제 등으로 인해 현실 적으로 어려움이 따른다. 따라서 치료 및 진단 목적으로 의뢰 
된 검사를 시행한 후 남은 잔여혈청을 수집하여 제조한 정도관 리물질을 이용하는 방법이 이에 대한 대안이 될 수 있겠다. 잔 여혈청을 수집하여 제조한 정도관리물질의 요건으로서는, 감 염성 물질이 아님이 확인되어야 하고, 분석물질의 농도가 용기 마다 균질하게 분주되어야 할 것이다. 또한 외부정도관리를 시 행하기 위한 정도관리물질은 충분한 기간 동안의 보관에도 안 정적이어야 하며, 장거리 배송 시에도 분석물질의 농도에 유의 한 차이를 일으키지 않는 안정성이 확보된 방법으로 보관되고 배송되어야 할 것이다[12].

체계적인 외부정도관리프로그램을 수행하기 위해서는 정 도관리물질의 종류나 보관온도, 보관조건에 따른 안정성을 사 전에 평가함이 필수적이다. 정도관리물질은 동결된(frozen) 혈청, 안정화된 액상(stabilized liquid) 혈청, 동결건조된 (lyophilized) 혈청의 세 가지 형태로 제조할 수 있다. 종양표 지자검사의 외부정도관리물질 제조에 대한 한 연구에서 동결 건조된 혈청이 동결된 혈청에 비하여 보관에 따른 안정성이 떨 어져서 동일 보관조건에서 보관한 동결건조 혈청의 종양표지 자 농도가 동결된 혈청보다 낮고 변이계수도 큰 것으로 보고 하였다[13]. 또한 동결건조 물질의 경우 동결된 혈청과는 달리 복원 시 기질적 차이로 인한 상호전환성(commutability)의 문 제점에도 유의해야 한다[14].

한편 시약 제조회사의 설명서에 따르면 혈청 HE4 농도는 $15^{\circ} \mathrm{C}-25^{\circ} \mathrm{C}$ 에서 5 시간, $2^{\circ} \mathrm{C}-8^{\circ} \mathrm{C}$ 에서 48 시간, $-20^{\circ} \mathrm{C}$ 에서 12 주 까지 안정성을 보이는 것으로 명시되어 있다. 본 연구에서도 $\mathrm{HE} 4$ 혼주혈청을 실온 $\left(20^{\circ} \mathrm{C}\right)$ 보관 시 24 시간부터 기저치에 비 해 유의한 감소를 보였고, 냉장보관 $\left(4^{\circ} \mathrm{C}\right)$ 시 24 시간까지 안정 한 것으로 나타났으며, 냉동보관 $\left(-20^{\circ} \mathrm{C}\right)$ 시 30 일까지 안정한 것을 확인할 수 있었다. 따라서 제조한 HE4 정도관리물질의 안정성은 시약제조회사의 설명서에 안내된 내용과 유사한 것 으로 평가되었다.

모의신빙도조사에서 참여기관 수가 충분치 않았지만 두 가 지 HE4 제품(Abbott 및 Roche) 사용처별로 평균, SD 및 CV 를 구하여 검토하였는데, 두 제품 사용기관 간에 $\mathrm{SD}$ 와 $\mathrm{CV}$ 의 차이를 보였다(Table 4). 동 기간 본 검사실이 참여하였던 CAP HE4 survey (2017 HUEP-B) 보고서에서도 본 연구와 유사하게 두 제품 사용기관 간에 $\mathrm{SD}$ 와 CV에 차이가 있는 것 을 확인할 수 있었고, 이러한 차이는 제품의 성능 차이에 기인 할 가능성이 있을 것으로 생각되었다(Table 5).

결론적으로, $\mathrm{HE} 4$ 검사 종료 후 수집한 잔여혈청을 이용하 여 제조한 세 농도의 HE4 정도관리물질은 용기마다 균질하였 고, 냉동보관 시 제조 후 30 일까지 안정성이 유지되는 것으로 평가되었다. 임상적으로 중요성이 높고 그 사용량이 급증하고
Table 5. Human epididymis protein 4 results of the participant summary in 2017 HUEP-B released by College of American Pathologists

\begin{tabular}{llccr}
\hline & $\begin{array}{c}\text { Manu- } \\
\text { facturer }\end{array}$ & $\begin{array}{c}\text { No. of } \\
\text { labora- } \\
\text { tories }\end{array}$ & $\begin{array}{c}\text { Mean } \pm \text { SD } \\
\text { (pmol/L) }\end{array}$ & CV (\%) \\
\hline HUEP-04 & Abbott & 17 & $293.3 \pm 24.7$ & 8.4 \\
& Roche & 14 & $240.1 \pm 5.9$ & 2.5 \\
HUEP-05 & All methods & 32 & $270.7 \pm 33.1$ & 12.2 \\
& Abbott & 17 & $159.9 \pm 14.0$ & 8.8 \\
& Roche & 14 & $135.5 \pm 3.1$ & 2.3 \\
& All methods & 32 & $150.0 \pm 16.3$ & 10.9 \\
HUEP-06 & Abbott & 17 & $66.8 \pm 7.0$ & 10.5 \\
& Roche & 14 & $61.3 \pm 1.8$ & 2.9 \\
& All methods & 32 & $64.0 \pm 6.1$ & 9.5 \\
\hline
\end{tabular}

The instruments were from the following companies: Abbott Laboratories (Abbott Park, IL, USA) and Roche Diagnostics GmbH (Mannheim, Germany).

Abbreviations: SD, standard deviation; $\mathrm{CV}$, coefficient of variation.

있는 HE4와 같은 중요한 종양표지자에 대하여 국내 외부정도 관리프로그램 마련을 통한 질 관리가 시급하다고 생각된다.

\section{감사의 글}

이 논문은 대한임상검사정도관리협회 2017년 학술연구비 지원에 의해 이루어진 것이다.

\section{REFERENCES}

1. National Cancer Center. Annual report of cancer statistics in Korea in 2016. http://ncc.re.kr/cancerStatsView.nc c?bbsnum $=438 \&$ searchKey=total \&searchValue $=$ \&pageN um $=1$ (Accessed May 21, 2019).

2. Andersen MR, Goff BA, Lowe KA, Scholler N, Bergan $\mathrm{L}$, Dresher CW, et al. Combining a symptoms index with CA 125 to improve detection of ovarian cancer. Cancer 2008;113:484-9.

3. Wei SU, Li H, Zhang B. The diagnostic value of serum HE4 and CA-125 and ROMA index in ovarian cancer. Biomed Rep 2016;5:41-4.

4. Jung KW, Won YJ, Kong HJ, Lee ES; Community of Population-Based Regional Cancer Registries. Cancer statistics in Korea: incidence, mortality, survival, and 


\section{Journal of LABORATORY MEDICINE and QUALITY ASSURANCE}

Anna Lee et al • External Quality Assessment of HE4

prevalence in 2015. Cancer Res Treat 2018;50:303-16.

5. Koshiyama M, Matsumura N, Konishi I. Clinical efficacy of ovarian cancer screening. J Cancer 2016;7:1311-6.

6. Soletormos G, Duffy MJ, Othman Abu Hassan S, Verheijen RH, Tholander B, Bast RC Jr, et al. Clinical use of cancer biomarkers in epithelial ovarian cancer: updated guidelines from the European Group on Tumor Markers. Int J Gynecol Cancer 2016;26:43-51.

7. Jacobs I, Bast RC Jr. The CA 125 tumour-associated antigen: a review of the literature. Hum Reprod 1989;4:1-12.

8. Duffy MJ, Bonfrer JM, Kulpa J, Rustin GJ, Soletormos G, Torre GC, et al. CA125 in ovarian cancer: European Group on Tumor Markers guidelines for clinical use. Int J Gynecol Cancer 2005;15:679-91.

9. Lin J, Qin J, Sangvatanakul V. Human epididymis protein 4 for differential diagnosis between benign gynecologic disease and ovarian cancer: a systematic review and metaanalysis. Eur J Obstet Gynecol Reprod Biol 2013;167:815.

10. Redman C, Duffy S, Bromham N, Francis K; Guideline
Development Group. Recognition and initial management of ovarian cancer: summary of NICE guidance. BMJ 2011;342:d2073.

11. Moore RG, McMeekin DS, Brown AK, DiSilvestro P, Miller MC, Allard WJ, et al. A novel multiple marker bioassay utilizing HE4 and CA125 for the prediction of ovarian cancer in patients with a pelvic mass. Gynecol Oncol 2009;112:40-6.

12. Ahn S, Park J, Kim YR, Kim JH, Kim HS. Stability of lyophilized pooled sera as quality control materials for tumor marker assays in external quality assessment. Clin Chim Acta 2017;471:233-42.

13. De Castro MD, Izquierdo A. Lyophilization: a useful approach to the automation of analytical processes? J Automat Chem 1990;12:267-79.

14. Ferrero CA, Carobene A, Ceriotti F, Modenese A, Arcelloni C. Behavior of frozen serum pools and lyophilized sera in an external quality-assessment scheme. Clin Chem 1995;41:575-80. 